\title{
Economic, energetic and environmental analysis of the waste management system of Reggio Calabria
}

\author{
Concettina Marino, Antonino Nucara, Giovanna Nucera, Matilde Pietrafesa \\ Department of Civil, Energy, Environmental and Material Engineering (DICEAM), \\ Mediterranea University of Reggio Calabria, Via Graziella-Feo di Vito, 8912 Reggio Calabria, \\ Italy
}

Email: matilde.pietrafesa@unirc.it

\begin{abstract}
In the last decades problems concerning waste disposal have assumed increasing interest due to the growth of their production and typologies following consumption escalation. In an advanced industrial society waste constitute one of the main aspects concerning environment protection; their impact is linked to material quantity, typology and persistence into the environment. A correct waste management must be included within an integrated strategy of sustainable development: among the necessary actions aimed to reduce flows to landfills, regulations particularly indicate reduction of resource use, energy recovery, use of waste as a resource. Until today in Italy a sustainable management system has not been implemented yet, making frequent use of temporary solutions which only delay the problem come up. Within this frame, in the paper a case study has been analysed, referring to the collection and delivery system of Urban Solid Waste in Reggio Calabria, carrying out an analysis of the management process from an economic, energetic and environmental point of view. Analysing the phases following the collection (waste selection, transport, treatment), a critical evaluation of the used technologies has been conducted, assessing cost, energy consumption and pollutant emission. The analysed case has finally been compared with different scenarios, showing increasing percentage of differentiated collection, relating them to the least advanced disposal modality, landfill.
\end{abstract}

Keywords: Waste, Recycling, Landfill, Greenhouse Gas Emission.

\section{INTRODUCTION}

The notion of waste as a residual to dismiss is present only in anthropic activities. In the nature, cycles are closed (i.e. carbon or water cycle), composed by a chain of biological and chemical processes: a process waste is used in other processes, at the end of which the initial status is re-established. Consequently, in the nature the notion of waste is not present, but only that of substance which transforms: natural ecosystems operate through natural processes, reconstituting substances and energy in their initial conditions.

On the contrary, as far as anthropic activity is concerned, any materials introduced on the market after use turn into waste as well as any production process generates wastes to be disposed of. In EU the production of urban waste $(U S W)$ like, after all, in other OCSE countries, has registered a continuous and progressive increase in the last decades, after the improvement of people's socio-economic conditions and of population and urban areas increase. Consequently, problems connected to waste management have assumed more and more critical and relevant proportions in both economic and environmental terms [1], [2].
In a developed industrial society, waste management today represents one of the main aspects concerning environment protection, to be tackled using an integrated and sustainable management, acting on treatment modalities and reducing fluxes to landfill and waste persistence in the environment, in the aim to mitigate or avoid (zero waste) its impact [3]-[7].

Waste emissions are relevant, characterized by presence of methane and carbon dioxide, released by decomposition of their biodegradable component. About one third of methane anthropogenic emissions in Europe can be ascribed to such source; by contrast, low percentages of carbon dioxide or nitrous oxide emissions can be referred to wastes. Consequently, methane emissions reductions in landfills represents a strong potential in global warming mitigation.

At standard level, program guidelines tend to avoid waste production or to use them as a resource [8]-[12] and indicate energy recovery among the most efficient actions of a sustainable waste management [13]-[19].

Moreover, it is important to dispose waste in plants close to production sites in order to avoid the relevant incidence of transport emissions. 


\section{URBAN SOLID WASTE DISPOSAL - METHODS AND ANALYSIS}

The waste management and treatment process is illustrated with reference to a case study, concerning USW disposal system of Reggio Calabria. Particularly an economic, energetic and environmental analysis of the different process phases has been effected.

The society which manages the service handles waste collection, transport and sending to recovery, effecting a material selection treatment before their final disposal.

\subsection{Case study: USW disposal system OFC}

Monthly urban solid waste production in the city and its amount of selected collection in 2015 (year in which the society started its collection service) are reported in Figure 1: it can be observed that the differentiated amount in 2015 was still low (equal to $17,5 \%$ ).

Referring to EWC (Europe Waste Code) the collected quantities have been reported in Figure 2, pointing out the analysed components.

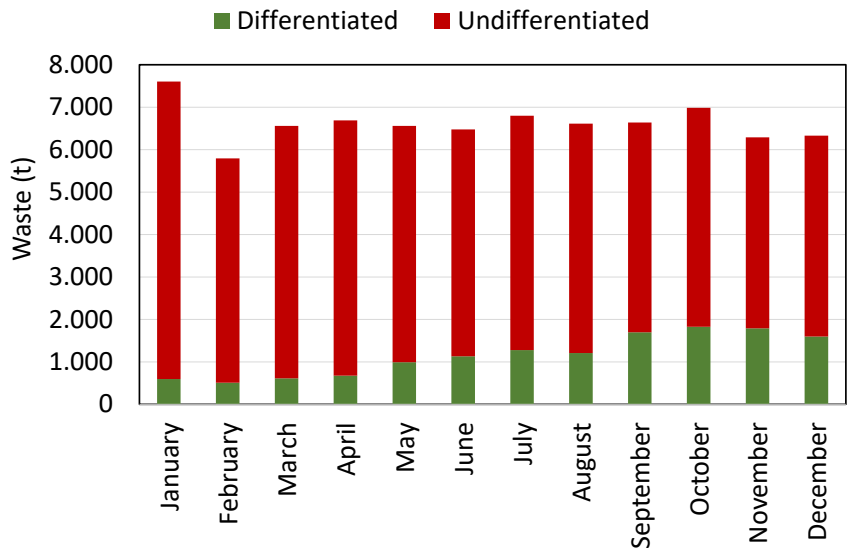

Figure 1. USW collected mass and differentiated percentage

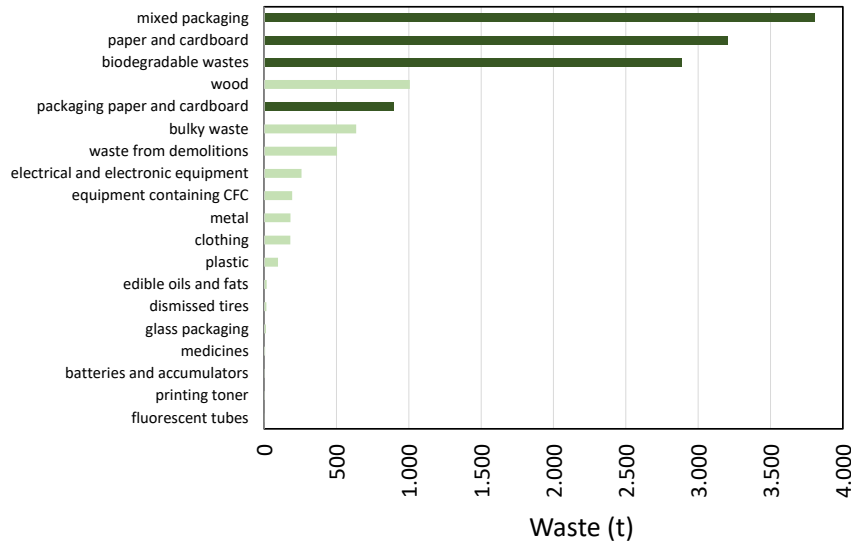

Figure 2. Waste quantity with reference to their classification according to $E W C$

Figure 3 reports the waste journey from the collection site to the disposal (for undifferentiated and organic components) or selection (for multi-material and paper) ones and the subsequent journey of selected materials to recycling plants.

Non-all the waste typologies are sent to treatment: in the analysed year only $75 \%$ of the selected component $(13,1 \%$ of total collected waste), formed by paper and cardboard, multimaterial and organic has been treated.

In undifferentiated waste, a part has been sent to stabilization and the remaining part to landfill.

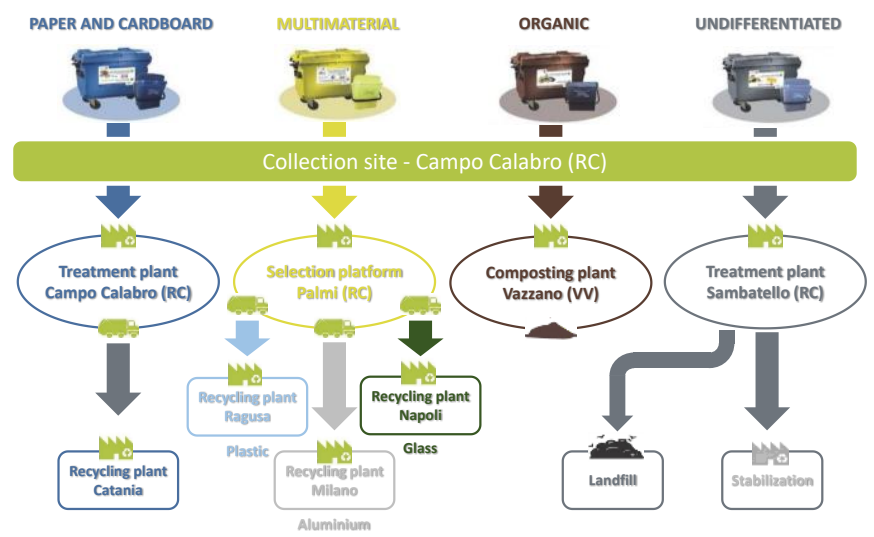

Figure 3. Waste components travel from the collection site to the selection, disposal and recycling sites

\subsection{Paper and cardboard}

After being collected, the paper and cardboard fraction is sent to a selection plant in order to remove impurities through manual selection. A subsequent pressing gives the final cubic form of bales, allowing easy loading and transport.

\subsection{Multi-material}

Multi-material includes different fractions simultaneously collected: plastic, glass and metals (aluminium) that are separated in a selection plant; glass and plastic are prevailing in volume and weight.

After a first manual selection, a dimensional reduction is carried out through an oscillating sieve, removing materials with large or very small dimensions.

Undersize materials are directed on a tape where, after a second manual selection of residual voluminous fractions, light materials (cans and plastic) are aeraulically separated through an extractor hood and metals are captured by an over belt magnet. The hood directs materials to a cyclone, where they fall into a hopper and are sent to a press in bales, distinguished by material (containers, white bottles, colored bottles, cans, and so on).

After a further manual selection, the material is sent to recycling, plastics after a subdivision by polymers (PET, PE, etc.) and colour, carried out by optical readers, that allow to obtain highly pure materials.

\subsection{Organic}

The fraction of organic waste is transformed in high quality fertilizing through a composting process, a biological stabilization in solid phase taking place in aerobic conditions.

Organic waste follows a precise treatment sequence. After a compliance test, waste is pre-treated through crumbling and mixturing and undergoes a primary biologic treatment aimed to remove through sieving metals and plastic.

The mixture of wet and wood-cellulose wastes (these latter, with structure function, are used for particularly wet waste) goes to composting in reinforced concrete basins covered by holed tiles, where it remains for 21-23 days; a periodic blowing 
of purified air by a bio-filter guarantees idoneous growth of bacteria in bio-oxidation phase.

\subsection{Undifferentiated waste}

Undifferentiated waste can be sent to landfill or to incinerators/waste to energy plants. In the analysed case, such component is sent to a treatment/transference plant, where materials are selected before their disposal in landfill.

\section{ECONOMIC ANALYSIS}

The economic analysis of the process includes the evaluation of costs and benefits for all the process phases (collection, transport to selection/disposal plants and to the recycling ones).
Due to the difficulties inherent the availability of collection costs, the present analysis has concerned all the process phases carried out after collection (transport, selection/disposal and recycling).

The related cost refers to transport and delivery to selection/disposal plants in a first phase (Step 1) and to transport to recycling plants in a second one (Step 2); the benefits consist in the proceeds of material sales to recycling plants (Step 2).

\subsection{Step 1. From collection to selection/disposal plants}

\subsubsection{Transport}

The transport cost from the waste collection site to the selection/disposal plants has been calculated (Table 1).

Table 1. Transport cost to selection plants

\begin{tabular}{llllllll}
\hline Origin & Destination & Waste & $\begin{array}{l}\text { Truck } \\
\text { capacity } \\
(\mathrm{t} / \text { vehicle })\end{array}$ & $\begin{array}{l}\mathrm{N} . \\
\text { trips }\end{array}$ & $\begin{array}{l}\text { Distance Time Cost } \\
(\mathrm{km})\end{array}$ & $\begin{array}{l}(\mathrm{h}) \\
(€)\end{array}$ \\
\hline $\begin{array}{l}\text { Campo Calabro } \\
(\mathrm{RC})\end{array}$ & Sambatello (RC) & Undifferentiated & 12 & $5{ }^{\prime} 453$ & 4.6 & 0.08 & $34^{\prime} 339$ \\
\hline $\begin{array}{l}\text { Campo Calabro } \\
(\mathrm{RC})\end{array}$ & Vazzano (VV) & Organic & 7.5 & 336 & 70.6 & 3 & $49^{\prime} 225$ \\
\hline $\begin{array}{l}\text { Campo Calabro } \\
(\mathrm{RC})\end{array}$ & Palmi (RC) & Multimaterial & 3 & $11^{\prime 2} 269$ & 29.5 & 1 & $68^{\prime} 371$ \\
\hline $\begin{array}{l}\text { Campo Calabro } \\
(\mathrm{RC})\end{array}$ & $\begin{array}{l}\text { Campo Calabro } \\
(\mathrm{RC})\end{array}$ & $\begin{array}{l}\text { Paper and } \\
\text { Cardboard }\end{array}$ & 4 & $1^{\prime} 025$ & 1.3 & 0.05 & $2^{\prime} 624$ \\
\hline
\end{tabular}

The $\operatorname{cost} C_{i}$ of i-th disposal modality has been determined using the expression:

$C_{i}=N_{i}\left[C_{d} \times d_{i}+C_{a} \times t_{i}\right]$

in which:

- $N_{i}$ is the number of trips:

$N_{i}=\frac{M_{\text {tot }}}{\text { Truck Capacity }}$

- $C_{d}$ is the travel cost referred to the $\mathrm{d}_{\mathrm{i}}$ distance. It consists of two rates, one referred to diesel consumption $(0.55 € / \mathrm{km})$ and another to vehicle usury $(0.3 € / \mathrm{km})$, for a total cost of $0.85 € / \mathrm{km}$

- $d_{i}$ is the distance from origin to destination $(\mathrm{km})$

- $C_{a}$ is the driver hourly cost $(28.76 € / \mathrm{h})$

- $t_{i}$ is time spent to travel $\mathrm{d}_{\mathrm{i}}$ distance (h).

3.1.2 Delivery to selecting/disposal plants

Table 2. Materials delivering costs to the selection plants

\begin{tabular}{llll}
\hline Waste & Quantity $(\mathrm{t})$ & Unit cost $(€ / \mathrm{t})$ & Total cost $(€)$ \\
\hline Undifferentiated & $65^{\prime} 438$ & 147.00 & $9^{\prime} 619^{\prime} 415$ \\
\hline Organic & $2^{\prime} 524$ & 96.61 & $243^{\prime} 795$ \\
\hline Multimaterial & $3^{\prime} 808$ & 205.00 & $780^{\prime} 681$ \\
\hline Paper and Cardboard & $4^{\prime} 099$ & 4.00 & $16 ' 398$ \\
\hline
\end{tabular}

Table 2 reports material delivering cost to selection plants.

\subsection{Step 2. From selection plants to recycling consortiums}

From the selection plants wastes are furtherly transported to the recycling consortiums.

The mass of each material coming out from the selection centres, reduced with respect to the one in entrance for the presence of product impurities, is determined hypothesizing that for multi-material it is $85 \%$ of the total collected one, whereas for paper, more easily perishable, only $50 \%$.

The weight percentages of multi-material components are: glass $(91 \%)$, plastic $(3 \%)$, aluminium $(6 \%)$.

\subsubsection{Transport}

Table 3. Step 2 transport cost

\begin{tabular}{llllllll}
\hline Origin & Destination Waste & $\begin{array}{l}\text { Truck } \\
\text { capacity } \\
(\mathrm{t} / \text { /vehicle })\end{array}$ & $\begin{array}{l}\text { N. } \\
\text { Trips }\end{array}$ & $\begin{array}{l}\text { Distance } \\
(\mathrm{km})\end{array}$ & $\begin{array}{l}\text { Time } \\
(\mathrm{h})\end{array}$ & $\begin{array}{l}\text { Cost } \\
(€)\end{array}$ \\
\hline Palmi (RC) & Naples & Glass & 25 & 118 & 582 & 8.31 & $86^{\prime} 463$ \\
\hline Palmi (RC) & Milan & Aluminium & 50 & 4 & $11^{\prime} 120$ & 16 & $5{ }^{\prime} 485$ \\
\hline Palmi (RC) & Ragusa & Plastic & 20 & 5 & 248 & 3.54 & 1 1'518 \\
\hline $\begin{array}{l}\text { Campo } \\
\text { Calabro (RC) }\end{array}$ & Catania & $\begin{array}{l}\text { Paper and } \\
\text { Cardboard }\end{array}$ & 25 & 82 & 108 & 1.54 & $11^{\prime} 165$ \\
\hline
\end{tabular}

Waste transport cost can be determined using the same analytical expression used in 3.1.1 (Table 3). It can be seen that the most expensive solution concerns glass transport to Naples, due to the large quantity of material. 


\subsubsection{Sales}

Table 4 reports the proceeds of waste sales to recycling plants.

Table 4. Proceeds of waste sales to recycling plants

\begin{tabular}{cccc}
\hline Waste & $\begin{array}{c}\text { Quantity } \\
(\mathrm{t})\end{array}$ & $\begin{array}{c}\text { Sales } \\
(€ / \mathrm{t})\end{array}$ & $\begin{array}{c}\text { Total sales } \\
(€)\end{array}$ \\
\hline Glass & $2^{\prime} 945$ & 303.00 & $892^{\prime} 529$ \\
\hline Aluminium & 194 & 15.00 & $2^{\prime} 913$ \\
\hline Plastic & 97 & 394.00 & $38^{\prime} 260$ \\
\hline Paper and cardboard & $2^{\prime} 049$ & 32.00 & $65^{\prime} 590$ \\
\hline
\end{tabular}

\subsubsection{Total cost}

Table 5. Total cost of waste management after collection

\begin{tabular}{|c|c|c|c|c|c|}
\hline \multirow{3}{*}{ Waste } & \multicolumn{5}{|l|}{ Cost $(€)$} \\
\hline & \multicolumn{2}{|l|}{ Step 1} & \multicolumn{2}{|l|}{ Step2 } & \multirow{2}{*}{ Total } \\
\hline & Transport & Disposal & Transport & Sales & \\
\hline Undifferentiated & 34'339 & $9^{\prime} 619^{\prime} 415$ & 0 & 0 & $9^{\prime} 653 ' 754$ \\
\hline Organic & $49^{\prime} 224$ & 243795 & 0 & 0 & 293'019 \\
\hline Glass & $62 ' 216$ & $710^{\prime} 419$ & $86^{\prime} 463$ & $-892 ' 529$ & $-333^{\prime} 431$ \\
\hline Aluminium & 4'102 & $46 ' 840$ & $5 ' 485$ & $-2^{\prime} 913$ & $53 ' 514$ \\
\hline Plastic & 2'051 & $23^{\prime} 420$ & $1 ' 518$ & $-38 ' 260$ & $-11 ' 271$ \\
\hline $\begin{array}{l}\text { Paper and } \\
\text { Cardboard }\end{array}$ & $2^{\prime} 623$ & 16397 & $11 ' 165$ & $-65^{\prime} 590$ & $-35 ' 405$ \\
\hline
\end{tabular}

The total economic fluxes, obtained from Tables 1-4, are reported in Table 5.

Due to the involved quantity, the most expensive disposal is

that referring to undifferentiated waste. Thanks to their sales, glass, plastic and card economic fluxes are in active.

\section{ENERGETIC AND ENVIRONMENTAL ANALYSIS}

Energetic assessments have been carried out evaluating fuel consumption necessary for transport and electric energy consumption required to select and recycle multi-material components.

Every waste during transport and treatment generates $\mathrm{CO}_{2}$ and other pollutant emissions, that have been determined using the related emission factor; as concerns $\mathrm{CO}_{2}$, the total amount emitted through the whole process has also been evaluated.

\subsection{Step 1. From the collection to the selection plants}

\subsubsection{Transport}

Fuel consumption $F C_{i}$ (diesel, $k g$ ) necessary to transfer the i-th waste to the plant has been determined using the expression:

$F C_{i}=N_{i} \times d_{i} \times f c$

where:

- $N_{i}$ is the number of required trips

- $d_{i}$ is the plant distance $(\mathrm{km})$

- $f c$ is the unitary fuel consumption $(0,42 \mathrm{~kg} / \mathrm{km})$.

The corresponding energy consumption $E_{i}(k W h)$ during the transport (Table 6) is then given by:

$E_{i}=F C_{i} \times L C V$

where LCV diesel Low Calorific Value (11,86 kWh/kg).

Table 6. Transport consumption

\begin{tabular}{|c|c|c|c|c|c|c|}
\hline Origin & Destination & Waste & $\begin{array}{l}\text { Distance } \\
(\mathrm{km})\end{array}$ & N. trips & $\begin{array}{l}\text { Consumption } \\
(\mathrm{kg} \text { fuel) }\end{array}$ & $\begin{array}{l}\text { Consumption } \\
(\mathrm{kWh})\end{array}$ \\
\hline $\begin{array}{l}\text { Campo Calabro } \\
\text { (RC) }\end{array}$ & Sambatello (RC) & Undifferentiated & 4.6 & $5^{\prime} 453$ & $10^{\prime} 536$ & $124^{\prime} 952$ \\
\hline $\begin{array}{l}\text { Campo Calabro } \\
(\mathrm{RC})\end{array}$ & Vazzano (VV) & Organic & 70.6 & 336 & $9^{\prime} 978$ & $118^{\prime} 343$ \\
\hline $\begin{array}{l}\text { Campo Calabro } \\
(\mathrm{RC})\end{array}$ & Palmi (RC) & Multimaterial & 29.5 & $1 ' 269$ & $15^{\prime} 743$ & $186 ' 712$ \\
\hline $\begin{array}{l}\text { Campo Calabro } \\
\text { (RC) }\end{array}$ & Campo Calabro (RC) & $\begin{array}{l}\text { Paper and } \\
\text { Cardboard }\end{array}$ & 1.3 & 1'025 & 568 & $6 ' 739$ \\
\hline
\end{tabular}

Moreover, $\mathrm{j}$-th pollutant emissions generated during the transport of the $\mathrm{i}$-th waste have been determined using the expression:

$e_{i j}=F C_{i} \times E F_{j}$

in which $E F_{j}(\mathrm{~g} / \mathrm{kg})$ is the emission factor of the j-th pollutant [20], [21] (Table 7). The results are reported in Table 8.

Table 7. Emission factors of the main combustion products [20]

\begin{tabular}{llllll}
\hline Pollutant & $\mathrm{CO}_{2}$ & $\mathrm{PM}$ & $\mathrm{CO}$ & $\mathrm{NO}_{\mathrm{x}}$ & $\mathrm{NH}_{3}$ \\
\hline $\begin{array}{l}\text { Emission factor } \\
\text { (g/kg fuel) }\end{array}$ & $3^{\prime} 140$ & 1.2 & 8 & 37 & 0.05 \\
\hline
\end{tabular}

Table 8. Step 1 Transport emissions

\begin{tabular}{llllll}
\hline \multirow{2}{*}{ Waste } & \multicolumn{5}{l}{ Emissions $(\mathrm{kg})$} \\
\cline { 2 - 6 } & $\mathrm{CO}_{2}$ & $\mathrm{PM}$ & $\mathrm{CO}$ & $\mathrm{NOx}$ & $\mathrm{NH}_{3}$ \\
\hline Undifferentiated & $33^{\prime} 082$ & 12.64 & 84.28 & 389.81 & 0.52 \\
\hline Organic & $31^{\prime} 332$ & 11.97 & 79.82 & 369.19 & 0.49 \\
\hline Multi-material & $49^{\prime} 436$ & 18.89 & 125.90 & 582.52 & 0.78 \\
\hline $\begin{array}{l}\text { Paper and } \\
\text { Cardboard }\end{array}$ & $1^{\prime} 784$ & 0.68 & 4.54 & 21.02 & 0.02 \\
\hline
\end{tabular}

\subsubsection{Selection/disposal}

Energy consumed by the selection of i-th waste $E_{i}$ has been evaluated through the expression:

$E_{i}=P_{i} \times t_{i} \times N_{d i}$ 
where

- $P_{i}$ plant power $(\mathrm{kW})$

- $t_{i}$ working time $(\mathrm{h})$

- $N_{d i}$ number of yearly working days.

Consequently, the $\mathrm{j}$-th pollutant emissions generated by the selection of i-th waste are computed through the expression:

$e_{i j}=E_{i} \times E F_{j}$

with $E F_{j}$ emission factor of the j-th pollutant $(\mathrm{kg} / \mathrm{kWh})$.

Using average values, we have made the hypothesis that plants are able to select $75 \mathrm{t} /$ day.

In Table 9 energy consumption, emission factors and $\mathrm{CO}_{2}$ emissions for multi material and paper selection are reported. Table 10 reports emission factors and Table 11 the related emissions of the main gases $\left(\mathrm{CH}_{4}\right.$ and $\left.\mathrm{CO}_{2}\right)$ originating from undifferentiated and organic wastes, which do not undergo energetic treatments.

Table 9. Energy consumption and $\mathrm{CO}_{2}$ emissions originating from multi material and paper selection

\begin{tabular}{|c|c|c|c|c|c|c|}
\hline Waste & $\begin{array}{l}\text { Plant } \\
\text { power } \\
(\mathrm{kW})\end{array}$ & $\begin{array}{l}\text { Working } \\
\text { time } \\
\text { (h) }\end{array}$ & $\begin{array}{l}\mathrm{N} \\
\text { days }\end{array}$ & $\begin{array}{l}\text { Energy } \\
(\mathrm{kWh})\end{array}$ & $\begin{array}{l}\text { Emission factor } \\
\left(\mathrm{kg} \mathrm{CO}_{2} / \mathrm{kWh}\right)\end{array}$ & $\begin{array}{l}\text { Emission } \\
\left(\mathrm{kg} \mathrm{CO}_{2}\right)\end{array}$ \\
\hline Multimaterial & 77 & 8 & 51 & 31456.8 & 0.22 & 6'920 \\
\hline $\begin{array}{l}\text { Paper and } \\
\text { Cardboard }\end{array}$ & 42 & 8 & 34 & 11451.2 & 0.22 & 2519 \\
\hline
\end{tabular}

It can be seen that very high emissions originate from undifferentiated waste, due to its quantity; the most relevant ones are ascribable to $\mathrm{CH}_{4}$, but also $\mathrm{CO}_{2}$ amount is noteworthy.

Table 10. Emission factors of the main landfill and organic gas emitted [22], [23]

\begin{tabular}{lllll}
\hline & \multicolumn{2}{l}{ Undifferentiated } & Organic & \\
\hline Pollutant & $\mathrm{CO}_{2}$ & $\mathrm{CH}_{4}$ & $\mathrm{CO}_{2}$ & $\mathrm{CH}_{4}$ \\
\hline $\begin{array}{l}\text { Emission factor } \\
\text { (t/t waste) }\end{array}$ & 0.87 & 23.68 & 0.396 & 4.00 \\
\hline
\end{tabular}

Table 11. Undifferentiated and organic components emissions

\begin{tabular}{cccc}
\hline \multirow{2}{*}{ Waste } & \multirow{2}{*}{ Quantity (t) } & \multicolumn{2}{c}{ Emissions (t) } \\
\cline { 3 - 4 } & & $\mathrm{CO}_{2}$ & $\mathrm{CH}_{4}$ \\
\hline Undifferentiated & $65^{\prime} 438$ & $56 ' 931$ & 1 1'549'572 $^{\prime}$ \\
\hline Organic & $2 ' 523$ & 999 & $10^{\prime} 092$ \\
\hline
\end{tabular}

\subsection{Step 2. From selection plants to recycling ones}

\subsubsection{Transport}

Fuel and energy consumption and the relative pollutant emissions have been calculated using the expressions described in 4.1.1. Table 12 reports the consumption values, Table 13 shows gas emissions, evaluated using emission factors reported in Table 7.

\subsubsection{Recycling}

The selected wastes undergo a recycling process. The plants unitary consumptions used in the analysis and the total energy consumption are reported in Table $14, \mathrm{CO}_{2}$ emissions are reported in Table 15 .
Table 12. Transport consumption

\begin{tabular}{lllllll}
\hline Origin & Destination & Waste & $\begin{array}{l}\text { Distance } \\
(\mathrm{km})\end{array}$ & $\begin{array}{l}\text { N. } \\
\text { trips }\end{array}$ & $\begin{array}{l}\text { Consumption } \\
(\mathrm{kg} \text { fuel })\end{array}$ & $\begin{array}{l}\text { Consumption } \\
(\mathrm{kWh})\end{array}$ \\
\hline Palmi (RC) & Naples & Glass & 581 & 118 & $28^{\prime} 795$ & $341^{\prime} 509$ \\
\hline Palmi (RC) & Milan & Aluminium & 1088 & 4 & $1^{\prime} 827$ & $21^{\prime} 670$ \\
\hline Palmi (RC) & Ragusa & Plastic & 241 & 5 & 506 & $5^{\prime} 998$ \\
\hline $\begin{array}{l}\text { Campo Calabro } \\
\text { (RC) }\end{array}$ & Catania & $\begin{array}{l}\text { Paper and } \\
\text { Cardboard }\end{array}$ & 108 & 82 & $33^{\prime} 719$ & $44^{\prime} 107$ \\
\hline
\end{tabular}

Table 13. Step 2 Transport emissions

\begin{tabular}{cccccc}
\hline \multicolumn{7}{c}{ Emissions $(\mathrm{kg})$} \\
\hline Waste & $\mathrm{CO}_{2}$ & $\mathrm{PM}$ & $\mathrm{CO}$ & $\mathrm{NO}_{\mathrm{x}}$ & $\mathrm{NH}_{3}$ \\
\hline Glass & $90^{\prime} 416,40$ & 34.55 & 230.36 & $1^{\prime} 065.42$ & 1.44 \\
\hline Aluminium & $5^{\prime} 737.12$ & 2.19 & 14.62 & 67.60 & 0.09 \\
\hline Plastic & $1^{\prime} 587.95$ & 0.61 & 4.05 & 18.71 & 0.03 \\
\hline $\begin{array}{c}\text { Paper and } \\
\text { Cardboard }\end{array}$ & $11^{\prime} 677.58$ & 4.46 & 29.75 & 137.60 & 0.19 \\
\hline
\end{tabular}

Table 14. Energy consumption by recycled material

\begin{tabular}{llll}
\hline Waste & $\begin{array}{l}\text { Quantity } \\
(\mathrm{t})\end{array}$ & $\begin{array}{l}\text { Unit Energy } \\
(\mathrm{kWh} / \mathrm{t})\end{array}$ & $\begin{array}{l}\text { Energy } \\
(\mathrm{kWh})\end{array}$ \\
\hline Glass & $2{ }^{\prime} 945$ & 4.30 & $12^{\prime} 664$ \\
\hline Aluminium & 194 & 0.85 & 165 \\
\hline Plastic & 97 & 15 & $1^{\prime} 455$ \\
\hline $\begin{array}{l}\text { Paper and } \\
\text { Cardboard }\end{array}$ & $2^{\prime} 049$ & 2.75 & $5^{\prime} 635$ \\
\hline
\end{tabular}

Table 15. Recycling $\mathrm{CO}_{2}$ emissions

\begin{tabular}{lll}
\hline Waste & $\mathrm{EF}\left(\mathrm{kgCO}_{2} / \mathrm{kWh}\right)$ & Emissions $\left(\mathrm{kgCO}_{2}\right)$ \\
\hline Glass & 0.22 & $2 ' 786$ \\
\hline Aluminium & 0.22 & 36 \\
\hline Plastic & 0.22 & 320 \\
\hline $\begin{array}{l}\text { Paper and } \\
\text { Cardboard }\end{array}$ & 0.22 & $1 ' 239$ \\
\hline
\end{tabular}

\subsubsection{Saved energy}

Saved energy by waste recycling has been evaluated as difference between energy consumed during production by raw material and from recycling.

Table 16. Production specific consumption

\begin{tabular}{ccc}
\hline Waste & $\begin{array}{c}\text { Production Energy } \\
\text { by raw material } \\
(\mathrm{kWh} / \mathrm{t})\end{array}$ & $\begin{array}{c}\text { Recycling Energy } \\
(\mathrm{kWh} / \mathrm{t})\end{array}$ \\
\hline Glass & 6.3 & 4.30 \\
\hline Aluminium & 16 & 0.85 \\
\hline Plastic & 45 & 15 \\
\hline Paper and Cardboard & 7.6 & 2.75 \\
\hline
\end{tabular}

From Table 16, reporting specific consumption referring to production by raw material and recycling, it can be seen that the greatest energy consumption is associated to plastic production $(45 \mathrm{kWh} / \mathrm{t})$, with reference to which the greatest energy saving is obtained $(30 \mathrm{kWh} / \mathrm{t})$, followed by that of 
aluminium (ca. $15 \mathrm{kWh} / \mathrm{t}$ ). In Table 17 and in Figure 4 the respective total energy consumptions are reported: due to the collected quantities, the greatest ones are observed for glass, the recycling of which allows saving only $2 \mathrm{kWh} / \mathrm{t}$. Moreover, Table 17 reports total emissions avoidable through recycling.

Table 17. Total consumption referred to production by raw material and recycling and relative avoidable emission

\begin{tabular}{ccccc}
\hline Waste & $\begin{array}{c}\text { Quantity } \\
(\mathrm{t})\end{array}$ & $\begin{array}{c}\text { Production energy } \\
\text { by raw material } \\
(\mathrm{MWh})\end{array}$ & $\begin{array}{c}\text { Recycling } \\
\text { Energy } \\
(\mathrm{MWh})\end{array}$ & $\begin{array}{c}\text { Avoided } \\
\text { emissions } \\
\left(\mathrm{tCO}_{2}\right)\end{array}$ \\
\hline Glass & $2^{\prime} 945$ & 18.6 & 12.7 & 1.3 \\
\hline Aluminium & 194 & 3.1 & 0.2 & 0.6 \\
\hline Plastic & 97 & 4.4 & 1.5 & 0.6 \\
\hline $\begin{array}{c}\text { Paper and } \\
\text { Cardboard }\end{array}$ & $2{ }^{\prime} 049$ & 15.6 & 5.6 & 2.2 \\
\hline
\end{tabular}

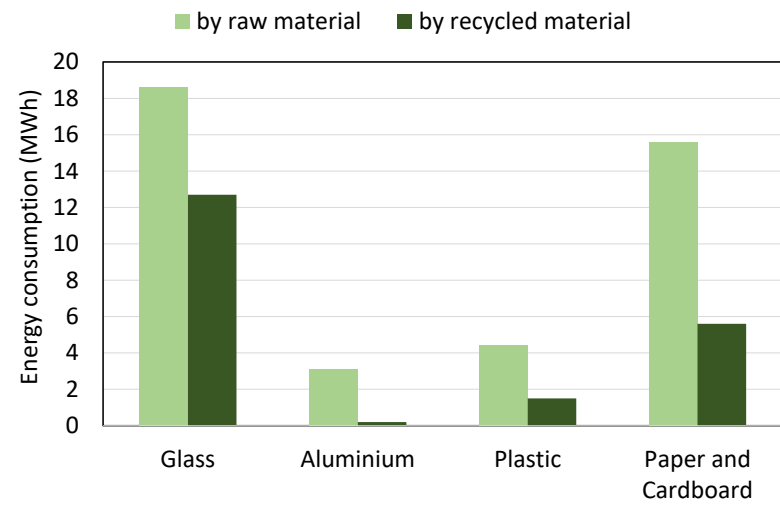

Figure 4. Energy consumption for material production

\subsubsection{Total consumption and emissions}

Table 18. Total energy consumption

\begin{tabular}{|c|c|c|c|c|c|}
\hline \multirow{3}{*}{ Waste } & \multicolumn{5}{|c|}{ Energy Consumption (MWh) } \\
\hline & \multicolumn{2}{|l|}{ Step 1} & \multicolumn{2}{|l|}{ Step2 } & \multirow{2}{*}{ Total } \\
\hline & Transport & Treatment & Transport & Treatment & \\
\hline Undifferentiated & 125.00 & & & & 125.00 \\
\hline Organic & 118.30 & 0.00 & & & 118.30 \\
\hline Glass & 169.89 & 28.63 & 342.00 & 12.66 & 553.18 \\
\hline Aluminium & 11.20 & 1.89 & 22.00 & 0.17 & 35.25 \\
\hline Plastic & 5.60 & 0.94 & 6.00 & 1.45 & 13.99 \\
\hline $\begin{array}{l}\text { Paper and } \\
\text { Cardboard }\end{array}$ & 6.70 & 0.11 & 44.00 & 0.04 & 50.85 \\
\hline
\end{tabular}

Table 19. Total $\mathrm{CO}_{2}$ emissions

\begin{tabular}{llllll}
\hline \multirow{2}{*}{ Waste } & \multicolumn{5}{l}{$\mathrm{CO}_{2}$ Emissions $(\mathrm{t})$} \\
\cline { 2 - 5 } & Step 1 & \multicolumn{3}{c}{ Step2 } \\
\cline { 2 - 5 } & Transport & Treatment & Transport & Treatment \\
\hline Undifferentiated & 33.00 & $56^{\prime} 931.00$ & & & $56^{\prime} 964.00$ \\
\hline Organic & 31.00 & 999.11 & & $11^{\prime} 030.11$ \\
\hline Glass & 44.59 & 6.30 & 90.42 & 2.78 & 144.09 \\
\hline Aluminium & 2.94 & 0.42 & 5.74 & 0.04 & 9.14 \\
\hline Plastic & 1.47 & 0.21 & 1.59 & 0.32 & 3.59 \\
\hline $\begin{array}{l}\text { Paper and } \\
\text { Cardboard }\end{array}$ & 1.78 & 2.52 & 11.70 & 1.24 & 17.24 \\
\hline
\end{tabular}

Total consumption and $\mathrm{CO}_{2}$ emissions referring to transport and treatment (Step 1 and 2) are reported in Tables 18 and 19.
Concerning multi-material components in Step 1, they have been determined using the respective weight percentages.

Due to the involved quantities, the most relevant emissions are originated from undifferentiated waste.

\subsubsection{Scenarios}

The analysed case has been compared with different scenarios (Table 20) showing increasing percentage of differentiated collection ( $35 \%$ and $70 \%$ ), relating them to the least advanced disposal modality, landfill. In Table 21 the total cost of waste management in the scenarios is reported. Moreover, Figures 6 and 7 respectively show the scenarios cost referring to waste components and phases of disposal Steps.

Table 20. Analysed scenarios

\begin{tabular}{ll}
\hline Scenario & Description \\
\hline 0 & $100 \%$ undifferentiated waste to landfill \\
\hline 1 & $17.5 \%$ differentiated waste (present case) \\
\hline 2 & $35.0 \%$ differentiated waste \\
\hline 3 & $70.0 \%$ differentiated waste \\
\hline
\end{tabular}

Table 21. Total cost of waste management for the scenario

\begin{tabular}{ccccc}
\hline \multirow{2}{*}{ Waste } & Cost $(€)$ & & & \\
\cline { 2 - 5 } & Scenario 0 & Scenario 1 & Scenario 2 & Scenario 3 \\
\hline Undifferentiated & $11^{\prime} 192^{\prime} 010$ & $9^{\prime} 653^{\prime} 754$ & $8^{\prime} 114^{\prime} 498$ & $5^{\prime} 0366^{\prime} 987$ \\
Organic & & $293^{\prime} 019$ & $5866^{\prime} 150$ & $1^{\prime} 172^{\prime} 300$ \\
Glass & & $-33^{\prime} 431$ & $-66^{\prime} 877$ & $-133^{\prime} 755$ \\
Aluminium & & $53^{\prime} 514$ & $107^{\prime} 015$ & $214^{\prime} 030$ \\
Plastic & & $-11^{\prime} 271$ & $-22^{\prime} 465$ & $-44^{\prime} 930$ \\
Paper and Cardboard & & $-35^{\prime} 405$ & $-87^{\prime} 224$ & $-174^{\prime} 448$ \\
\hline TOTAL & $11^{\prime} 192^{\prime} 010$ & $9^{\prime} 919^{\prime} 753$ & 8'631'097 $^{\prime} 6$ 6’070'183 $^{\prime}$
\end{tabular}

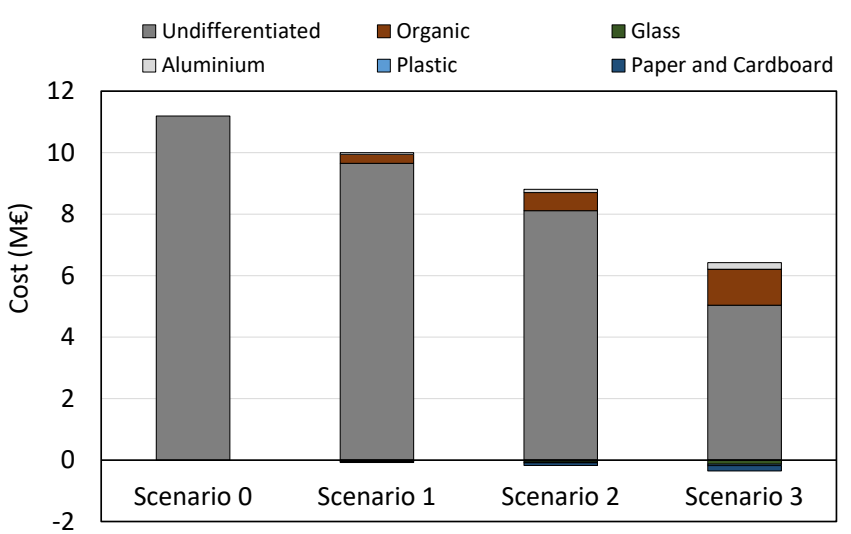

Figure 6. Cost of waste management scenarios referred to waste components

Particularly in Figure 7, referring to each phase of the two steps, also benefits can be represented, differently from Figure 6 , which reports the final cost (or benefit) associated to each material disposal. It can be observed that, due to the recyclable material sales, increasing the percentages of differentiated collection can markedly reduce scenarios costs. 


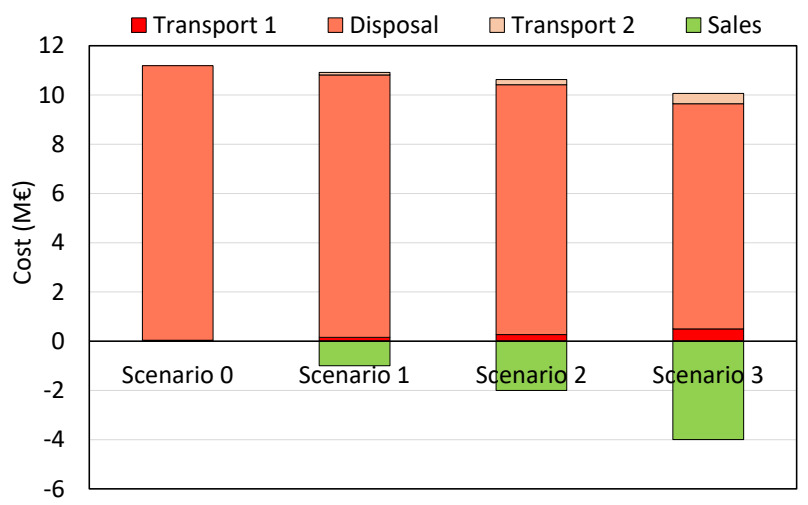

Figure 7. Cost and benefit of waste management scenarios referred to the Steps phases

Table 22. Scenarios total energy consumption

\begin{tabular}{lllll}
\hline \multicolumn{5}{c}{ Total energy consumption (MWh) } \\
\hline Waste & Scenario 0 & Scenario 1 & Scenario 2 & Scenario 3 \\
\hline Undifferentiated & 144.88 & 125.00 & 105.04 & 65.21 \\
\hline Organic & & 118.30 & 237.03 & 473.70 \\
\hline Glass & 553.18 & 1 '’079.70 & 2'159.39 \\
\hline Aluminium & 33.25 & 69.51 & 139.02 \\
\hline Plastic & 13.99 & 25.08 & 50.16 \\
\hline $\begin{array}{l}\text { Paper and } \\
\text { Cardboard }\end{array}$ & 50.85 & 119.98 & 239.96 \\
\hline TOTAL & 144.88 & 896.58 & 1'636.33 $^{\prime}$ & 3'127.46 \\
\hline
\end{tabular}

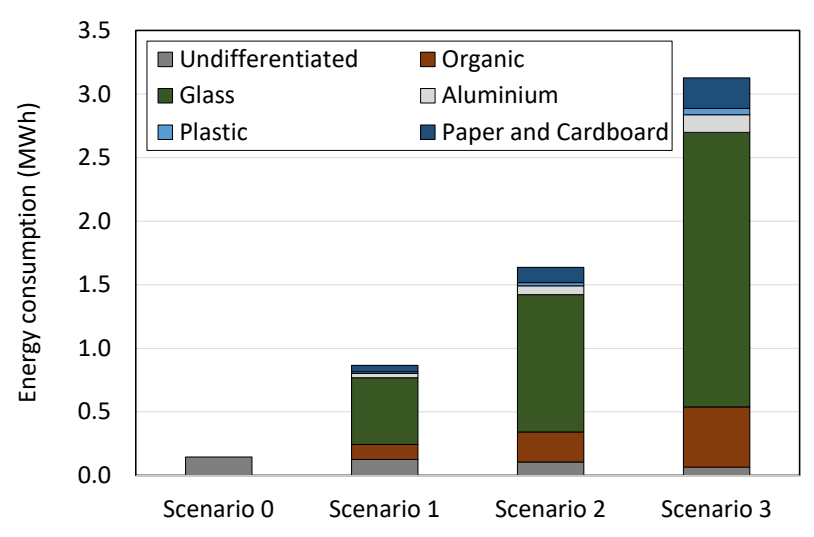

Figure 8. Scenarios energy consumption referred to waste components.

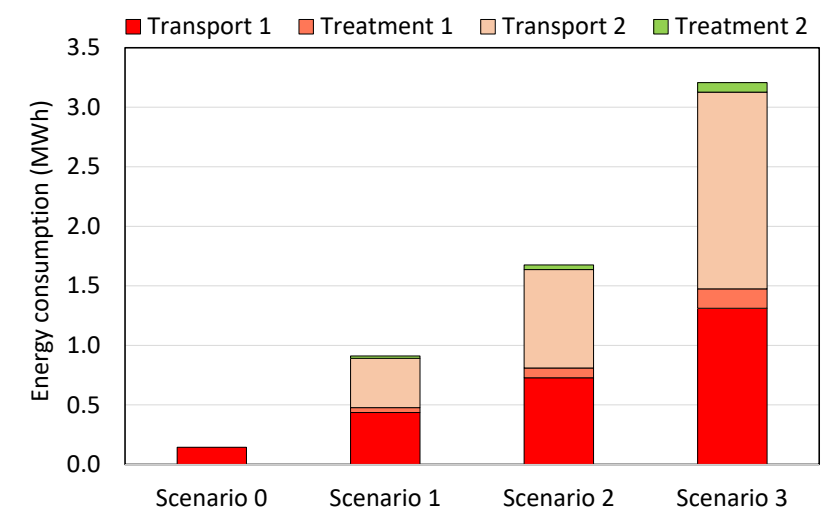

Figure 9. Scenarios energy consumption referred to Steps.
In Table 22 and Figures 8-9 the scenarios total consumptions are reported: the figures respectively refer to waste components and disposal steps. As it is possible to observe, consumption markedly increase as the percentage of differentiated selection increases, but this is pre-eminently due to the distance of the glass recycling plant.

Finally, Table 23 and Figures 10-11 show the corresponding scenarios $\mathrm{CO}_{2}$ emissions; the figures respectively refer to waste components and Steps phases.

Table 23. Scenarios $\mathrm{CO}_{2}$ emissions

\begin{tabular}{ccccc}
\hline \multicolumn{5}{c}{$\mathrm{CO}_{2}$ emissions (t) } \\
\hline Waste & Scenario 0 & Scenario 1 & Scenario 2 & Scenario 3 \\
\hline Undifferentiated & $66^{\prime} 044.39$ & $56^{\prime} 964.00$ & $47^{\prime} 883.90$ & 29’723.42 \\
\hline Organic & & 1’030.11 & 2’061.76 & 4’123.43 \\
\hline Glass & 144.09 & 288.87 & 577.74 \\
\hline Aluminium & 9.14 & 18.31 & 36.62 \\
\hline Plastic & 3.59 & 7.20 & 14.39 \\
\hline $\begin{array}{c}\text { Paper and } \\
\text { Cardboard }\end{array}$ & 17.24 & 33.42 & 66.84 \\
\hline TOTAL & $66^{\prime} 044.39$ & $58^{\prime} 168.16$ & $50^{\prime} 293.45$ & $34^{\prime} 542.43$ \\
\hline
\end{tabular}

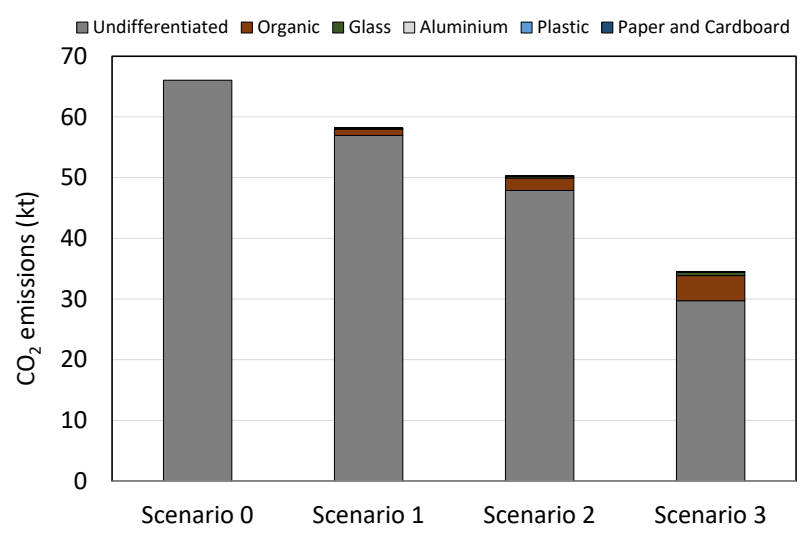

Figure 10. Scenarios $\mathrm{CO}_{2}$ emissions referred to components.

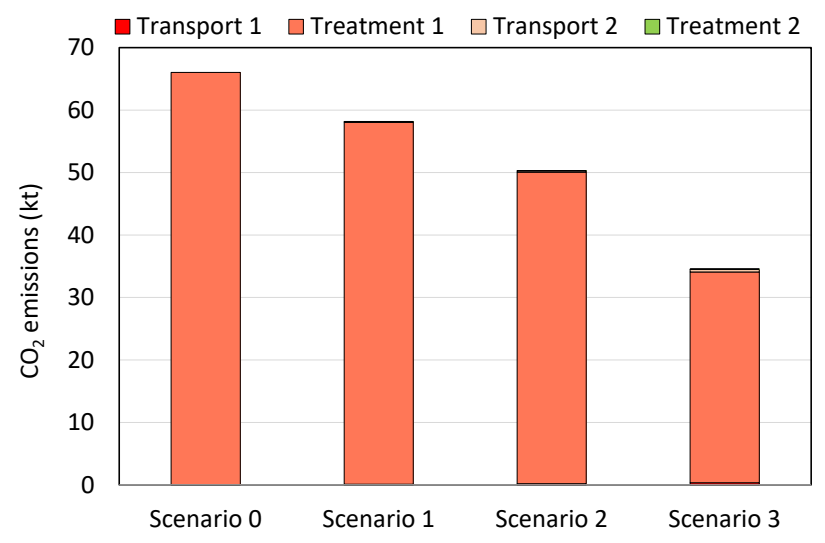

Figure 11. Scenarios $\mathrm{CO}_{2}$ emissions referred to Steps phases.

It can be observed that, like cost, also $\mathrm{CO}_{2}$ emissions reduce in advanced scenarios, thanks to the reduced quantities sent to landfill: for $70 \%$ differentiated selection, $\mathrm{CO}_{2}$ amount becomes half the value observed in the analysed case $(17,5 \%)$. 


\section{CONCLUSIONS}

The management of urban solid waste (USW), in continuous and progressive increase in the last decades, has become one of the most important aspects concerning environment protection; its impact must be mitigated acting on the treatment modalities, recovering energy and reducing fluxes to landfill.

Within this frame, in the paper a case study has been analysed, concerning USW management in the city of Reggio Calabria, effecting an analytic evaluation, from an economic, energetic and environmental point of view, of the phases after collection (selection, transport, recycling), assessing costs and benefits, energy consumption and pollutant emissions.

From the energetic point of view, fuel consumption required for transport and energy necessary for selection and recycling have been evaluated; the related emissions have been calculated for the transport combustion products, for $\mathrm{CO}_{2}$ emitted during the selection/treatment processes and the nonenergetic ones, where also $\mathrm{CH}_{4}$ emission has been computed.

From the economic point of view, the most relevant contribution, due to the delivery cost of large waste quantities into landfill, resulted that of undifferentiated waste; limitedly to transport, differently, the greater cost is imputable to glass.

Being the landfill close to the city, it is not responsible of the greatest consumption that, on the contrary, is associated to glass and pre-eminently due to the transport of its large quantities to Naples to be recycled. To such component is also associated the greatest saved energy for recycling, despite of the small unitary savings ( $2 \mathrm{kWh} / \mathrm{t}$ against $30 \mathrm{kWh} / \mathrm{t}$ of plastic).

As concerns emissions, the contribution of landfill is by far prevailing due to the relevant disposed quantities, followed by that of organic. For both the most relevant emissions are ascribable to $\mathrm{CH}_{4}$, but also $\mathrm{CO}_{2}$ amount is noteworthy, above all in comparison to that emitted by other components.

A comparison with different scenarios, showing increasing percentage of differentiated collection (35\% and $70 \%)$, has been carried out, relating them to the least advanced disposal modality, landfill

It can be observed that, due to the recyclable material sales, increasing the percentages of differentiated collection can markedly reduce scenarios costs. Also, emissions reduce in advanced scenarios, thanks to the reduced waste quantities sent to landfill disposal: when differentiated selection reaches $70 \%$, $\mathrm{CO}_{2}$ amount becomes half the value observed in the analysed case $(17,5 \%$ differentiated selection)

Differently, energy consumption markedly increases as the percentage of differentiated selection increases, pre-eminently due to the distance of the glass recycling plant.

\section{REFERENCES}

[1] Burnley S.J. (2007). A review of municipal solid waste composition in the United Kingdom, Waste Manag., Vol. 27, No. 10, pp. 1274-1285. DOI: 10.1016/j.wasman.2006.06.018

[2] Cannistraro G., Cannistraro M., Cannistraro A., Galvagno A. (2016). Analysis of air pollution in the urban center of four cities Sicilian, Int. J. Heat Technol., Vol. 34, No. Special Issue 2, pp. S219-S225. DOI: 10.18280/ijht.34S205

[3] Ferreira F., Avelino C., Bentes I., Matos C., Teixeira C.A. (2017). Assessment strategies for municipal selective waste collection schemes, Waste Manag., Vol.

59, pp. 3-13. DOI: 10.1016/j.wasman. 2016.10.044

[4]

Azapagic A., Perdan S., Clift R. (2004). Sustainable development in practice: case studies for engineers and scientists, Chichester, West Sussex, England.

[5] Shekdar A.V. (2009). Sustainable solid waste management: An integrated approach for Asian countries, Waste Manag., Vol. 29, No. 4, pp. 14381448. DOI: 10.1016/j.wasman.2008.08.025

[6] Cherubini F., Bargigli S., Ulgiati S. (2009). Life cycle assessment (LCA) of waste management strategies: Landfilling, sorting plant and incineration, Energy, Vol. 34, No. 12, pp. 2116-2123. DOI: 10.1016/j.energy.2008.08.023

[7] Al-Salem S.M., Evangelisti S., Lettieri P. (2014). Life cycle assessment of alternative technologies for municipal solid waste and plastic solid waste management in the Greater London area, Chem. Eng. J. Vol. 244, pp. 391-402. DOI: 10.1016/ j.cej.2014.01.066

[8] Al-Salem S.M., Lettieri P., Baeyens J. (2009). Recycling and recovery routes of plastic solid waste (PSW): A review, Waste Manag., Vol. 29, No. 10, pp. 2625-2643. DOI: 10.1016/j.wasman.2009.06.004

[9] Jeswani H.K., Azapagic A. (2016). Assessing the environmental sustainability of energy recovery from municipal solid waste in the UK, Waste Manag., Vol. 50, pp. 346-363. DOI: 10.1016/j.wasman. 2016.02.010

[10] Cardinale T., Arleo G., Bernardo F., Feo A., De Fazio P. (2017). Investigations on thermal and mechanical properties of cement mortar with reed and straw fibers, in 11th AIGE 2017 2st AIGE/IIETA Int. Conf.

[11] Baccilieri F., Bornino R., Fotia A., Marino C., Nucara A., Pietrafesa M. (2016). Experimental measurements of the thermal conductivity of insulant elements made of natural materials: preliminary results, in 10th AIGE 2016 1st AIGE/IIETA Int. Conf., pp. 1-7.

[12] Marino C., Nucara A., Pietrafesa M., Polimeni G. (2017). Natural and waste materials as building insulating elements: experimental measurements of thermal conductivities, (accepted for presentation), in SDEWES17 - 12th Dubrovnik Conf. Sustain. Dev. Energy Water Environ. Syst. Oct. 4 - 8, Dubrovnik, Croat.

[13] Liamsanguan C., Gheewala S.H. (2006). Environmental assessment of energy production from municipal solid waste incineration, Int. J. Life Cycle Assess., Vol. 12, No. 7, pp. 529. DOI: 10.1065/lca2006.10.278

[14] Jeswani H.K., Smith R.W., Azapagic A. (2013). Energy from waste: carbon footprint of incineration and landfill biogas in the UK, Int. J. Life Cycle Assess., Vol. 18, No. 1, pp. 218-229. DOI: $10.1007 / \mathrm{s} 11367-012-0441-8$

[15] Astrup T.F., Tonini D., Turconi R., Boldrin A. (2015). Life cycle assessment of thermal Waste-to-Energy technologies: Review and recommendations, Waste Manag., Vol. 37, pp. 104-115. DOI: 10.1016/j.wasman.2014.06.011

[16] Browne J.D., Murphy J.D. (2013). Assessment of the resource associated with biomethane from food waste, Appl. Energy, Vol. 104, pp. 170-177. DOI: 10.1016/j.apenergy.2012.11.017

[17] Zhang C., Xiao G., Peng L., Su H., Tan T. (2013). The anaerobic co-digestion of food waste and cattle manure, Bioresour. Technol., Vol. 129, pp. 170-176. DOI: 
10.1016/j.biortech.2012.10.138

[18] Appels L., Baeyens J., Degrève J., Dewil R. (2008). Principles and potential of the anaerobic digestion of waste-activated sludge, Prog. Energy Combust. Sci., Vol. 34, No. 6. pp. 755-781. DOI: 10.1016/j.pecs.2008.06.002

[19] Calabrò P.S., Panzera M.F. (2017). Biomethane production tests on ensiled orange peel waste, in 11th AIGE 2017 2st AIGE/IIETA Int. Conf.

[20] EMEP/EEA air pollutant emission inventory guidebook - 2016, EEA Report No 21/2016, Copenhagen K Denmark, 2016.

[21] Marino C., Nucara A., Pietrafesa M., Pudano A. (2016). The assessment of road traffic air pollution by means of an average emission parameter, Environ. Model. Assess., Vol. 21, No. 1. pp. 53-69. DOI: 10.1007/s10666-015-9489-8

[22] Eggleston S., Buendia L., Miwa K., Ngara T., Tanabe K. (2006). 2006 IPCC Guidelines for National Greenhouse Gas Inventories.

[23] De Stefanis P., Landolfo P.G., Mininni G. (1998).
Gestione dei rifiuti ad effetto serra, in Conf. Naz. Energ. e Ambient, ENEA.

\section{NOMENCLATURE}

C cost of disposal modality, $€$

$C_{a} \quad$ hourly driver cost, $€ / \mathrm{h}$

$C_{d} \quad$ unitary travel cost, $€ / \mathrm{km}$

$d \quad$ distance, $\mathrm{km}$

$e \quad$ pollutant emissions, $\mathrm{g}$

$E \quad$ energy consumption, $\mathrm{kWh}$

$E F \quad$ pollutant emissions factor, $\mathrm{g} / \mathrm{kg}$ fuel

$f c$ unitary fuel consumption, $\mathrm{kg}$ fuel $/ \mathrm{km}$

$F C$ fuel consumption, $\mathrm{kg}$ fuel

LCV low calorific value, $\mathrm{kWh} / \mathrm{kg}$

$M_{\text {tot }} \quad$ total waste mass, $\mathrm{t}$

$N \quad$ number of trips

$N_{d} \quad$ number of days

$P \quad$ power plant, $\mathrm{kW}$

$t \quad$ time, $\mathrm{h}$ 